\title{
TWO CYCADS NILSSONIA MIROVANAE SP. NOV. AND PSEUDOCTENIS BABINENSIS J.KVAČEK FROM THE CENOMANIAN OF THE BOHEMIAN CRETACEOUS BASIN (THE CZECH REPUBLIC) AS INDICATORS OF WATER STRESS IN THE PALAEOENVIRONMENT
}

\author{
JANA ČEPIČKOVÁ ${ }^{1,2}$, JIŘÍ KVAČEK ${ }^{2, *}$ \\ ${ }^{1}$ Institute of Geology and Palaeontology, Faculty of Science, Charles University, Albertov 6, Praha 2, 128 43, the Czech Republic; \\ e-mail: cepickoj@natur.cuni.cz. \\ 22National Museum, Václavské náměstí 68, 11000 Praha 1, the Czech Republic; e-mail: jiri.kvacek@nm.cz, jana.cepickova@nm.cz. \\ * corresponding author
}

Čepičková, J., Kvaček, J. (2020): Two cycads Nilssonia mirovanae sp. nov. and Pseudoctenis babinensis J.KvačEK from the Cenomanian of the Bohemian Cretaceous Basin (the Czech Republic) as indicators of water stress in the palaeoenvironment. Fossil Imprint, 76(2): 315-324, Praha. ISSN 2533-4050 (print), ISSN 2533-4069 (on-line).

\begin{abstract}
Nilssonia mirovanae sp. nov. is described from the Late Cretaceous Cenomanian of the Bohemian Cretaceous Basin. It comes from the best-exposed portion of the Peruc-Korycany Formation, in the Pecínov quarry, west of Prague, the Czech Republic. Although preserved only as a fragment of a pinna, it clearly shows haplocheilic stomata. In this paper, we compare N. mirovanae with Pseudoctenis babinensis J.KVAČEK from the same horizon. These two cycads have similar adaptations for surviving water stress: thick cuticles and sunken stomata, characteristic features among gymnosperms indicating adaptation to drought.
\end{abstract}

Key words: xeromorphic plants, cuticle analysis, Late Cretaceous

Received: October 10, 2020 | Accepted: November 14, 2020 | Issued: December 30, 2020

\section{Introduction}

Gymnosperms are typical components of mid-Cretaceous floras, although their percentage quickly decreased soon after, due to the expansion of angiosperms. This decrease is traceable since the mid-Early Cretaceous, mainly in river flood plains (Friis et al. 2019). Fluvial sediments of the Peruc-Korycany Formation show the same pattern (Uličný et al. 1997), but the Peruc Flora still contains a quite high percentage of Early Cretaceous relict species, including Sagenopteris C.PrESL in Sternberg (1838), Eretmophyllum H.H.THOMAs (Kvaček 1999, Kvaček et al. 2005), three leaf taxa of Bennettitales, one stem of Cycadeoidea BucKLAND ex Lindl. et HutTon nom. illegit. (Němejc 1968, Kvaček 1994, 1995, Knobloch and Kvaček 1997), and numerous cycads including leaves of Pseudoctenis Seward, Jirusia E.BAyer, Nilssonia Brongn., and ovuliferous cones of Microzamia Corda in Reuss (1846) (Kvaček 1995, 1997, 2008, Kvaček and Knobloch 1997).

Pseudoctenis babinensis (Kvaček 1995) and Nilssonia mirovanae are cycads equipped with a very thick cuticle, a feature characteristic for xeromorphic plants.

A description of these two cycad species is the main purpose of this paper. Additionally, epidermal characters of
Pseudoctenis babinensis and Nilssonia mirovanae are evaluated as indicators of water stress in the palaeoenvironment.

\section{Material and methods}

The studied plant fossils come from the Peruc-Korycany Formation of the Bohemian Cretaceous Basin, as defined by Čech et al. (1980) and Čech (2011). The Peruc-Korycany Formation is situated in the basal-most position of the basin, preserving continental, coastal and shallow marine sediments. The studied material was collected in the Pecínov quarry, situated $50 \mathrm{~km}$ west of Prague (Text-figs 1, 2; Uličný et al. 1997, 2009, Kvaček et al. 2006). The plant fossils come from fluvial sediments, interpreted as originating in a small braided river. This sediment is labeled unit 1 (Uličný et al. 1997). Fluvial deposits of unit 1 (Textfig. 2) comprise fragments of charcoalified leaves of ferns, leaves and reproductive structures of lauroid angiosperms (Eucalyptolaurus CoIfFARD et al. and Mauldinia DrinNAN et al., Pragocladus J.KvAČEK et EKLund; Eklund and Kvaček 1998, Kvaček and Eklund 2003), and platanoid angiosperms 

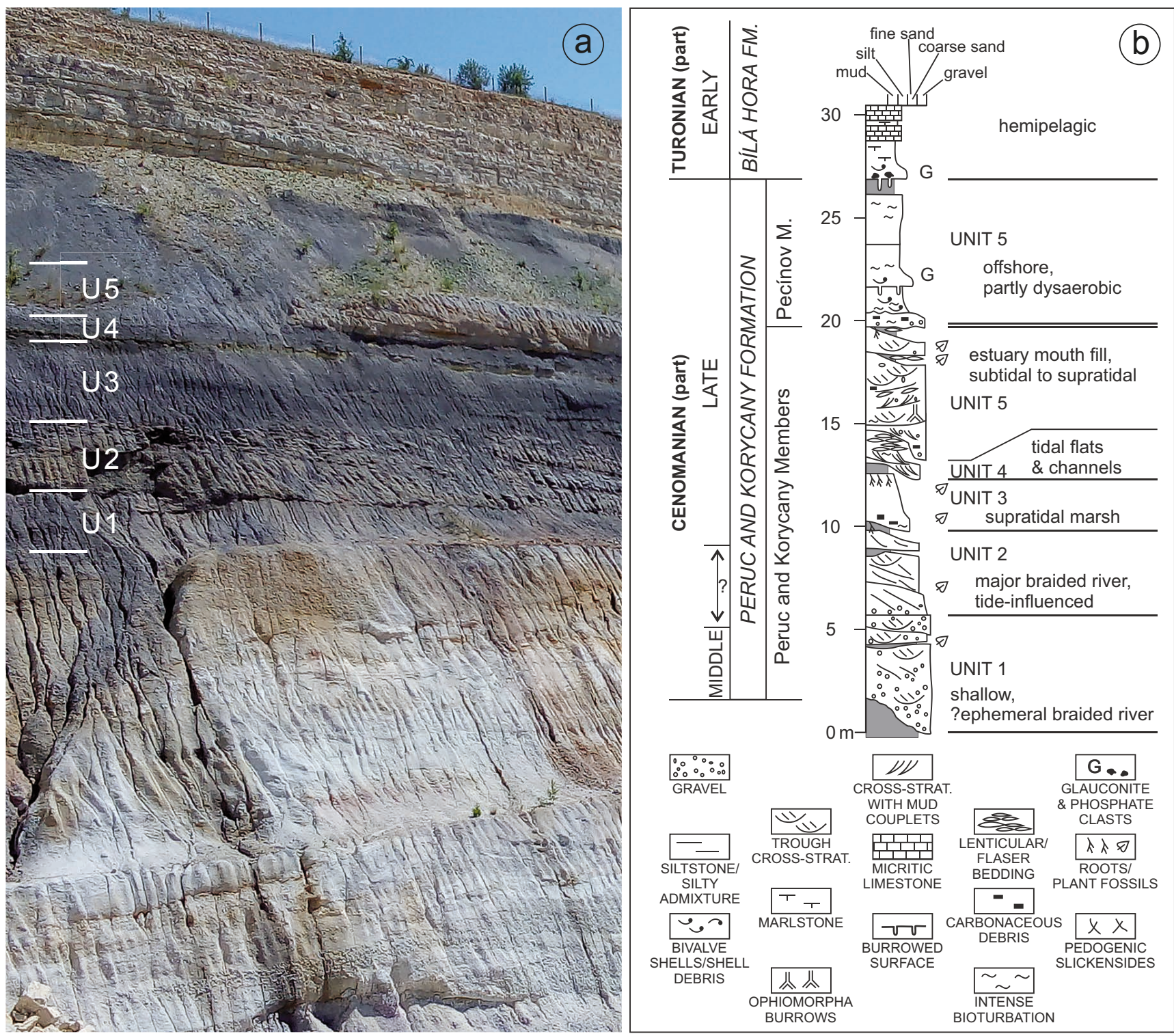

Text-fig. 1. Geological situation. a: Section showing deposits of Peruc-Korycany Formation in Pecínov Quarry - units 1-5. b: Summary of facies and units (UNIT 1-5) of Peruc-Korycany Formation. UNIT 1 - shallow braided river, UNIT 2 - major braided river, tide-influenced, UNIT 3 - supratidal marsh, UNIT 4 - tidal flats and channels, UNIT 5 - estuary mouth fill, subtidal to supratidal. Adapted from Uličný et al. 1997.

(Ettingshausenia StIEHLER, Platananthus MAnCHESTER; Kvaček 2003). In lesser numbers, there are reported leaves of cycads (Pseudoctenis SEWARD, Nilssonia Brongn.; Kvaček and Knobloch 1997, Kvaček 2008), conifers (Brachyphyllum Brongn., Pagiophyllum HeEr; Kvaček 2007), and chloranthoid angiosperms (Araliaephyllum FONTAINE).

The material was collected in 2016 by Jiři Kvaček and Jaromír Váňa. All the studied plant fossils, including cuticle preparations, are housed in the National Museum, Prague, the Czech Republic (NM). The fossil material was studied and documented using an Olympus SZX-12 binocular microscope equipped with a DP70 digital camera. For study of micromorphology of leaf epidermis, cuticle analysis was applied, summarized in Kerp (1990). The leaf fragments were mechanically separated from the rock with a needle. The residual silicate components were separated by hydrofluoric acid (HF). After rinsing in water, the cuticle was macerated in Schulze's reagent (saturated solution $\mathrm{HNO}_{3}$ with crystal of $\mathrm{KClO}_{3}$ ) for $20 \mathrm{~min}$. in case of $P$. babinensis and $30 \mathrm{~min}$. in case of $N$. mirovanae, and again rinsed in water. In the last step, the cuticle was treated in potassium hydroxide $(\mathrm{KOH})$, washed in water and stored in distilled water. The separated cuticles were mounted in glycerin for optical microscopy. The studied material was documented using an Olympus BX 50 light microscope equipped with a DP-72 digital camera. For SEM studies, cuticles were fixed on a small sheet of negative photo film mounted on aluminium stubs. The stubs with sheets and cuticle were coated with gold for 60 seconds in a sputter coater and examined using a Hitachi S-3700N SEM.

The new name of the Nilssonia species is registered with a unique PFN number in the Plant Fossil Names Registry, hosted and operated by the National Museum, Prague for the International Organisation of Palaeobotany (IOP). 


\section{Systematic palaeobotany}

\section{Order Cycadales Pers. ex Bercht. et J.Presl, 1820}

\section{Genus Pseudoctenis Seward, 1911}

Ty p e. Zamites eathiensis T.RICHARDS, 1884, p. $117 \equiv$ Pseudoctenis eathiensis (T.Richards) SEWARD, 1911, p. 692, pl. 6, figs 1-3, pl. 7, figs 1-6.

Remarks. Pseudoctenis and Ctenis Lindu. et HutTon differ mainly in their venation patterns. Ctenis has anastomosing veins (Lindley and Hutton 1834). By contrast with Pseudoctenis, Nilssonia typically has lamina attached to the upper side of the rachis, its segmentation is irregular, stomata in some cases surrounded by papillae and the secondary veins never fork (Harris 1964).

The newly collected material consists of only one pinna fragment. However, its parallel, occasionally forking veins and cuticle with haplocheilic stomata surrounded by numerous subsidiary cells and thick cuticle clearly indicate that the fragment belongs to the genus Pseudoctenis. Pseudoctenis is based on type P. eathiensis (T.RICHARDS) SEWARD, as shown and revised by Van Konijnenburg-van Cittert et al. (1998). P. babinensis was described from the Pecínov locality by Kvaček (2008).

\section{Pseudoctenis babinensis J.KVAČEK, 2008}

Pl. 1, Figs $1-8$

2008 Pseudoctenis babinensis J.KVAČEK, p. 126, pl. 1, figs 1-7, pl. 2, figs 1-6.

Holotype. NM-F 2448 (coll. National Museum, Prague, the Czech Republic).

Studied material. NM-F 4597c.

D e s c r i p t i o $\mathrm{n}$. The holotype is a simply pinnate frond showing a robust rachis with typical longitudinal ridges. Pinnae are linear-lanceolate, entire-margined with attenuate apex. Venation of pinna is parallel.

The newly collected and studied specimen is a fragment of an entire-margined pinna (Pl. 1, Fig. 1). The length of the specimen is $45 \mathrm{~mm}$ and the width is $7 \mathrm{~mm}$. The fragment has parallel venation with a density of 13 veins per $10 \mathrm{~mm}$. The simple, occasionally forking veins run parallel to the leaf margins. The base and apex are not preserved. The leaf is hypostomatic. Adaxial cuticle bears isodiametric, polygonal ordinary cells $(40-70 \times 20-40 \mu \mathrm{m})(\mathrm{Pl}$. 1, Figs $7,8)$. Their anticlinal walls range from straight to curved and their thickness is $6-10 \mu \mathrm{m}$. Ordinary epidermal cells of the abaxial cuticle are isodiametric, tetragonal to polygonal $(40-90 \times 20-50 \mu \mathrm{m})(\mathrm{Pl}$. 1, Figs 4, 6). The anticlinal walls are straight to curved and their thickness is $6-10 \mu \mathrm{m}$.

Abaxial cuticle consists of isodiametric, polygonal to quadrangular epidermal ordinary cells $(40-90 \times 20-50 \mu \mathrm{m})$, with anticlinal walls, ranging from straight to curved. Thickness of periclinal wall is $8-10 \mu \mathrm{m}$. Stomata are irregularly scattered on abaxial cuticle. Their axes are partially randomly oriented, partially oriented parallel to pinna margin (Pl. 1, Figs 4, 6). Stomata are haplocheilic with 7-9 subsidiary cells, $20-50 \mu \mathrm{m}$ long and 25-60 $\mu \mathrm{m}$ wide. Ledges of guard cells are 45-55 $\mu \mathrm{m}$ long $\times 7-11 \mu \mathrm{m}$ wide (Pl. 1, Figs 3-6). Stomata are sunken in stomatal chambers and surrounded by slightly raised cutinized rims (Pl. 1, Fig. 2).

Discussion. The studied material was compared to the type material of P. babinensis (Kvaček 2008). Based on macromorphology and cuticle micromorphology similar haplocheilic stomata surrounded by high number of subsidiary cells, it is concluded this material is conspecific with the type. However, due to the small size of the studied specimen, it was not possible to determine and compare distribution of stomata in costal and intercostals zones of the studied material and the type.

\section{Genus Nilssonia BrongN., 1825}

Ty p e. Nilssonia brevis BRongn., 1825, p. 218, pl. 12, fig. 4.

Remarks. This genus was revised by Van Konijnenburg-van Cittert et al. (2017); ortography of the name was discussed and conserved as Nilssonia (with double 's') by Wang (2011).

The studied material is a fragment of an isolated straplike entire-margined pinna showing parallel arrangement of simple veins, and cuticle with papillae on subsidiary cells. These characters indicate genera Zamites BRONGN, 1828, Pseudoctenis, Nilssonia or Tilingia Watson et Cusack, 2005, nom. illegit. (non Tilingia Regel et Tiling 1859, Nouv. Mém. Soc. Imp. Naturalistes Moscou 11: 97). Other genera, such as Ctenis, Jirusia and Dioonopsis J.Horiuchi et T.Kimura differ from the studied material more profoundly in venation pattern and the presence of marginal teeth. The studied material differs from Zamites (and all bennettites) in absence of syndetocheilic stomata. The material in hand differs from the genus Tilingia in having stomata irregularly scattered across the pinna width. The pinna of the studied material does not differ in macromorphology from Pseudoctenis, but according to other observations, Pseudoctenis does not have papillae on subsidiary cells. This character does occur in some species of Nilssonia (Daber 1957, Van Konijnenburgvan Cittert and van der Burgh 1989, Barbacka 2001).

\section{Nilssonia mirovanae sp. nov.}

P1. 2, Figs 1-9

H o lo ty pe. NM-F 4698, designated here, housed in the National Museum, Prague, the Czech Republic (Pl. 2, Figs 1-9).

Plant Fossil Names Registry Number: PFN001825.

Etymology. The generic name is derived from the name of Jaromír (Miro) Váňa, who collected plant fossils in Pecínov quarry during his long-term service for the National Museum.

Type locality. Pecínov quarry, $50 \mathrm{~km}$ west of Prague, the Czech Republic

Type horizon. Peruc-Korycany Formation, unit 1.

A g e. Cenomanian, Late Cretaceous.

Diagnosis. Isolated strap-like entire-margined pinna fragment, venation running parallel to pinna margin, 
veins simple. Pinna hypostomatic, adaxial cuticle bearing elongate, rectangular ordinary cells, straight to slightly wavy anticlinal walls. Each ordinary cell bearing a pronounced ridge in its central part. Abaxial cuticle consisting of costal and intercostal zones, costal zones built by elongate, rectangular ordinary cells of the same type as those on the adaxial side; intercostal zones consisting of isodiametric to shortly elongate ordinary cells. Stomata, arranged in rows, haplocheilic surrounded with 4-6 (7) subsidiary cells each bearing a papilla, overhanging the stomatal pit; guard cells sunken. Stomatal axes orientated parallel to pinna margin. Ledges of dorsal thickenings of guard cells pronounced.

Description. The holotype, and only known specimen, is a leaf compression - pinna fragment from a larger pinnate leaf (Pl. 2, Fig. 1). The specimen is a strap-shaped fragment of an entire-margined pinna. It is symmetric, $61 \mathrm{~mm}$ long and $6 \mathrm{~mm}$ wide. Veins are simple, running parallel to pinna margin. Venation density is $2-3$ veins per $\mathrm{mm}$.

The leaf is hypostomatic. Its adaxial cuticle comprises elongated rectangular ordinary cells, 40-90 $\mu \mathrm{m}$ long and 10-25 $\mu \mathrm{m}$ wide. Anticlinal walls are straight, rarely slightly wavy; their thickness is $4-6 \mu \mathrm{m}$ (Pl. 2, Figs 6, 8). The abaxial cuticle consists of costal and intercostal zones (P1. 2, Figs 2-5). The width of the costal zones is $200 \mu \mathrm{m}$, the intercostal zones $220 \mu \mathrm{m}$. The costal zones are formed by elongate ordinary cells, similar to those on the adaxial cuticle. The outer surfaces of the costal zones show parallel ridges (Pl. 2, Figs 3, 5). The intercostal zones consist of isodiametric to slightly elongated ordinary cells, 40-80 $\mu \mathrm{m}$ long and 10-20 $\mu \mathrm{m}$ wide (P1. 2, Figs 2, 4). The periclinal wall of ordinary cells is smooth, showing parallel ridges, its thickness varies from 5 to $10 \mu \mathrm{m}$. The intercostal zones consist of three to four rows of stomata. Stomatal rows are separated by 1-3 ordinary cells (Pl. 2, Figs 2, 4, 9). The stomatal axes are oriented parallel to the pinna margin (P1. 2, Fig. 9). The anticlinal walls are nearly straight or slightly bent. The stomata are haplocheilic (Pl. 2, Figs 4, 9), surrounded with 4-6 (7) subsidiary cells 20-60 $\mu \mathrm{m}$ long and $15-30 \mu \mathrm{m}$ wide. They are sunken in stomatal chambers 25-30 $\mu \mathrm{m}$ long $\times 5-20 \mu \mathrm{m}$ wide. Each subsidiary cell shows externally 3-6 (7) large papillae. The papillae surround the stomatal chamber from the outside (Pl. 2, Figs 5, 7).

\section{Discussion}

Two species of Nilssonia described from the PerucKorycany Formation of the Bohemian Cretaceous Basin, Nilssonia bohemica Velen. from the locality Praha - Malá Chuchle (Velenovský 1885, Kvaček 1994, Kvaček and Knobloch 1997) and Nilssonia holyi J.KvAČEK et ERW. KNOBLOCH (Kvaček and Knobloch 1997) from the locality of Pecínov have undivided or nearly undivided leaves, in contrast to $N$. mirovanae, which is a fragment of a simply pinnate leaf. Nilssonia mirovanae shows pronounced dorsal thickenings of guard cells, and stomata surrounded by papillae regularly placed in rows with stomatal axes oriented parallel to the pinna margin, in contrast to $N$. bohemica and $N$. holyi that show stomata without dorsal thickenings of guard cells and without papillae. Additionally, their stomata are irregularly scattered in intercostal zones (Kvaček and Knobloch 1997), in contrast to $N$. mirovanae, which has stomata oriented parallel to the pinna margin.

Leaves of Nilssonia stenoneura (AUg.SCHENK) DABER from the Jurassic of Germany (Schenk 1867, Daber 1957) have undivided or nearly undivided lamina, in contrast to $N$. mirovanae, which is a fragment of a simply pinnate leaf. The cuticle of $N$. stenoneura shows similar papillae on subsidiary cells to those observed in $N$. mirovanae. $N$. stenoneura differs from $N$. mirovanae in having stomata oriented irregularly. Ordinary cells do not show ridges, as does N. mirovanae.

Nilssonia polymorpha Aug.SCHENK from the Early Cretaceous of Germany, described by Schenk (1867), has undivided or irregularly divided leaf lamina. It resembles $N$. mirovanae in having papillate subsidiary cells, however, $N$. polymorpha shows larger papillae and does not show stomata oriented parallel to pinna margin (Schenk 1867), nor ridges on ordinary cells.

Nilssonia obtusa (NATH.) T.M.HARRIs from the Early Jurassic of Greenland (Nathorst 1878, Harris 1932) has an undivided lamina, in which character it differs from $N$. mirovanae. In cuticle pattern it differs from $N$. mirovanae in the absence of papillae on subsidiary cells. N. obtusa described from the Hungarian Liassic has occasional occurrence of small papillae on subsidiary cells (Barbacka 2001). N. obtusa does not show ridges on ordinary cells.

Nilssonia revoluta T.M.HARRIS from the Jurassic of Scarborough, Yorkshire, described by Harris (1964), has entire and downwards curved leaf margins. Nilssonia revoluta shows isodiametric to elongate ordinary epidermal cells on the abaxial cuticle, similar to $N$. mirovanae. It also shows randomly oriented stomata on a very delicate lower cuticle, in which it differs from N. mirovanae. Nilssonia species identified by Barbacka (2001) as N. revoluta from Hungary is characterized by very pronounced papillae directed towards the stomatal chambers, and lower stomatal density. Additionally, its cutinized ridges are two or three on ordinary cells, and are not straight and long, as they are in N. mirovanae.

Nilssonia culgowerensis VAN KonIJNENB. et BURGH from the Late Jurassic of Culgower, Scotland (Van Konijnenburgvan Cittert and van der Burgh 1989), is similar to N. mirovanae in shape of pinnae and dorsal thickenings of guard cells. It has irregularly oriented stomatal axes, in contrast to $N$. mirovanae, which has stomata arranged parallel to pinna margin. Additionally, it does not show cutinized ridges on ordinary cells, which $N$. mirovanae does.

Nilssonia syllis T.M.HARRIS from the Jurassic of Yorkshire, described by Harris (1964), is quite similar to $N$. mirovanae in shape of pinnae. However, it differs from $N$. mirovanae in having inconspicuous, randomly oriented stomata. Stomata of $N$. syllis are sunken and enclosed in a pit of six subsidiary cells, each bearing hollow papillae. Similarly to $N$. culgoverensis, it does not show cutinized ridges on ordinary cells, which $N$. mirovanae does.

Nilssonia compta (J.PHILliPs) BRONGN. from the Jurassic of Yorkshire (Harris 1964) differs from N. mirovanae in having broader and irregular pinnae. Its stomata are irregularly scattered and surrounded by rather small papillae. Its ordinary cells lack distinctly cutinized ridges. 
Nilssonia sturii KRASSER from the Late Triassic of Lunz (Krasser 1909, emend. Pott et al. 2007) is quite similar to $N$. mirovanae in shape of pinnae and prominent dorsal thickenings of guard cells. However, $N$. sturii differs from $N$. mirovanae in having a quite delicate cuticle, lacking papillae on subsidiary cells and ridges on ordinary cells, and in having stomata irregularly oriented.

Other simply pinnate species of Nilssonia show either cuticle without papillae, like Nilssonia lunzensis C.Potт, Kerp et M.Krings from the Late Triassic of Lunz (Pott et al. 2007), N. kendallii T.M.HARris and N. tenuicaulis (J.PHILliPS) BRONGN. from the Jurassic of Yorkshire (Harris 1964), or do not have preserved cuticle at all (Nilssonia serotina HeER from the Late Cretaceous of Sakhalin; Gnilovskaya 2016).

Pseudoctenis lanei H.H.Thomas from the Jurassic of Yorkshire, described by Thomas (1913), shows the same type of pinna as $N$. mirovanae. The lower cuticle of $P$. lanei bears mostly evenly scattered stomata oriented predominantly parallel to the pinna margin. In this character it is quite similar to $N$. mirovanae. However, $P$. lanei bears a variable quantity of large, thick-walled papillae, mostly irregularly scattered on ordinary cells, in contrast to $N$. mirovanae, which shows quite smooth periclinal walls and papillate subsidiary cells. Additionally, P. lanei lacks the papillate subsidiary cells and the dorsal thickenings of guard cells found in stomata of $N$. mirovanae.

\section{Palaeoecological remarks}

Unit 1 of the Pecínov section (Text-fig. 2) is a sedimentary body built of psammitic sediments, predominantly sandstones with small mudstone interbeds (Uličný et al. 1997). It is interpreted as a braided river with channels 1-10 m wide and $0.5-1 \mathrm{~m}$ deep. Massive conglomerates fill these channels, consisting of coarse to medium-grained sandstones and mudstones. All these sedimentological textures indicate an environment of small braided river that flowed through a hilly landscape. The mudstones are rich in leaves of angiosperms and charcoalified fragments of ferns. (Uličný et al. 1997). Fragments of Pseudoctenis babinensis and Nilssonia mirovanae are very rare (4 babinensis and 1 mirovanae to date), but have always been found in association with other Brachyphyllum-type xerophytic/mesophytic conifers (Kvaček 2007) and bennettits (JK unpubl. data). Fragmentary preservation of studied fossil plants indicates that these leaf fragments underwent substantial transport before burial in sediment. Due to this type of preservation in river sediment, we consider them allochthonous. Their cuticle micromorphology indicates that these plants were adapted to moderate water stress.

Among gymnosperms, a thick cuticle is a characteristic feature for xeromorphic plants ( Veromann-Jürgenson et al. 2019). Fahn and Cutler (1992) summarized and described features of recent xeromorphic (but not succulent) plants. Cuticles of both of the studied taxa are strongly cutinized and show sunken stomata, in the case of Nilssonia mirovanae, the stomata are also surrounded by papillae, all of which are again characters of xeromorphic plants (Fahn and Cutler 1992). The fossil plants show very similar or even identical cuticle characters that are known to be present in extant xeromorphic plants, so according to the uniformitarian principle (Scott 1963), we consider it likely that the fossil plants were also xeromorphic.

Leaves of Pseudoctenis babinensis show epidermal cells with anticlinal walls $6-10 \mu \mathrm{m}$ thick. The species is further characterized by stomata embedded in stomatal chambers.

Nilssonia mirovanae has a very similar mechanism to survive drought. It shows cuticle 4-6 $\mu \mathrm{m}$ thick and stomata embedded in stomatal chambers. Ridges, wrinkles and papillae, characteristic for xeromorphic plants (Fahn and Cutler 1992) are also present in the cuticle of $N$. mirovanae. There are typically 3-6 (7) papillae surrounding and externally protecting each stoma.

From the above information, the vegetation of the unit 1 is preliminarily interpreted as flood-plain angiosperm-dominated gallery forest of a river that was surrounded by more xeric fern savannah, with solitary occurring xeromorphic Brachyphyllum-type conifers, cycads and bennettits. Seasonally dry environment is indicated by CLAMP (Herman et al. 2002, JK unpubl. data) and growthring analyses of charcoalified wood (Greguš et al. 2020).

\section{Acknowledgements}

We are grateful to Jaromír Váňa for his help with collecting the fossil material, Lenka Váchová (National Museum Prague, the Czech Republic) for technical assistance with photography and the scanning electron microscopy, and Petr Daneš for English editing. We are also grateful to workers of the Pecínov quarry for their long-term cooperation and support of our field work. Additionally, we highly appreciate numerous suggestions of the reviewers Johanna van Konijnenburg-van Cittert, Evelyn Kustatscher, Christian Pott and Milan Libertín. This research was supported by a grant project of the Czech Grant Agency No. 20-06134S.

\section{References}

Barbacka, M. (2001): The cycads of Hungarian Liassic. Revue de Paléobiologie, 20(2): 525-541.

Berchtold, B. W., Presl, J. S. (1820): O prrirozenosti rostlin, aneb, Rostlinár [About the nature of plants, or Planter]. K. W. Enders, Praha, 322 pp. (in Czech)

Brongniart, A. (1825): Observations sur les végétaux fossils renfermés dans les grès de Hoer en Scanie. - Annales des sciences naturelles, 4: 200-219.

Brongniart, A. (1828): Histoire des vegétaux fossiles ou recherches botaniques et géologiques sur les végétaux renfermés dans les diverses couches du globe.-Muséum national d'Histoire naturelle de Paris, Paris, 136 pp. https://doi.org/10.5962/bhl.title.60992

Čech, S. (2011): Palaeogeography and stratigraphy of the Bohemian Cretaceous Basin (Czech Republic) - an overview. - Geologické výzkumy na Moravě a ve Slezsku, 18(1): 18-21.

Čech, S., Klein, V., Kř́̌ž, J., Valečka, J. (1980): Revision of the Upper Cretaceous stratigraphy of the Bohemian Cretaceous Basin. - Věstník Ústředního ústavu geologického, 55: 277-296. 
Daber, R. (1957): Kleine Lias-Flora aus der Bohrung Bernheide bei Wittenberge. - Geologie, 6(3): 306-315.

Eklund, H., Kvaček, J. (1998): Lauraceous inflorescences and flowers from the Cenomanian of Bohemia (Czech Republic, Central Europe) - International Journal of Plant Sciences, 159: 668-686. https://doi.org/10.1086/297585

Fahn, A., Cutler, D. F. (1992): Xerophytes (Encyclopedia of Plant Anatomy, vol. XIII.3). - Gebruder Borntraeger Verlagsbuchhandlung, Stuttgart, $176 \mathrm{pp}$.

Friis, E. M., Crane, P. R., Pedersen, K. R. (2019): The Early Cretaceous mesofossil flora of Torres Vedras (NE of Forte da Forca), Portugal: a palaeofloristic analysis of an early angiosperm community. - Fossil Imprint, 75(2): 153-257. https://doi.org/10.2478/if-2019-0013

Gnilovskaya, A. (2016): Distribution and variability of Nilssonia serotina Heer (Cycadales) in the Cretaceous and Paleogene floras of northern Pacific Region. Palaeobotany, 7: 56-65.

https://doi.org/10.31111/palaeobotany/2016.7.56

Greguš, J., Kvaček, J., Sakala, J. (2020): Charcoalified homoxylous woods from the Cenomanian of the Bohemian Cretaceous Basin (Czech Republic). - Review of Palaeobotany and Palynology, 282: 104311 (9 pp.). https://doi.org/10.1016/j.revpalbo.2020.104311

Harris, T. M. (1932): The fossil flora of Scoresby Sound East Greenland, part 2: Description of seed plants incertae sedis together with a discussion of certain cycadophytes cuticles. - Meddelelser om Grønland, 85(3): 1-114.

Harris, T. M. (1964): The Yorkshire Jurassic Flora, II: Caytoniales, Cycadales and Pteridosperms. - The British Museum (Natural History), London, 191 pp.

Herman, A. B., Spicer, R. A., Kvaček, J. (2002): Late Cretaceous climate of Euroasia and Alaska: a quantitative palaeobotanical approach. - In: Wagreich, M. (ed.), Aspects of Cretaceous Stratigraphy and Palaeobiology. Österreichische Akademie der Wissenschaften, Schriftenreihe der Erdwissenschaftlichen Kommissionen, 15: 93-108.

Kerp, H. (1990): The study of fossil gymnosperms by means of cuticular analysis. - Palaios, 5: 548-569. https://doi.org/10.2307/3514861

Knobloch, E., Kvaček, J. (1997): Bennettitalean and coniferalean leaves from the Cretaceous (Cenomanian) of the Bohemian Massif, Central Europe. - Cretaceous Research, 18: 567-586. https://doi.org/10.1006/cres.1997.0074

Krasser, F. (1909): Zur Kenntnis der fossilen Flora der Lunzer Schichten. - Jahrbuch der Kaiserlich-Königlichen Geologischen Reichsanstalt, 59: 1-26.

Kvaček, J. (1994): Nilsonia and Nilsonia-like leaves from the Cenomanian of Bohemia. - Acta Universitatis Carolinae, Geologica, 1992(1-2): 63-71.

Kvaček, J. (1995): Cycadales and Bennettitales leaf compressions of the Bohemian Cenomanian, Central Europe. - Review of Palaeobotany and Palynology, 84: 389-412. https://doi.org/10.1016/0034-6667(94)00093-Y

Kvaček, J. (1997): Microzamia gibba (Reuss) Corda: A cycad ovulate cone from the Bohemian Cretaceous Basin, Czech Republic - micromorphology and reinterpretations of its affinities. - Review of Palaeobotany and Palynology, 96: 81-97.

https://doi.org/10.1016/S0034-6667(96)00047-4

Kvaček, J. (1999): New data and revision of three gymnosperms from the Cenomanian of Bohemia Sagenopteris variabilis (Velenovský) Velenovský, Mesenea bohemica (Corda) comb. n. and Eretmophyllum obtusum (Velenovský) comb. n. - Acta Musei Nationalis Pragae, Series B - Historia Naturalis, 55(1-2), 15-24.

Kvaček, J. (2003): Platanoid staminate inflorescence and its associated foliage from the Bohemian Cenomanian (Czech Republic). - Acta Universitatis Carolinae, Geologica, 47: 67-72.

Kvaček, J. (2007): The conifer Brachyphyllum squamosum from the Bohemian Cenomanian. - Acta Palaeobotanica, 47(1): 25-35.

Kvaček, J. (2008): New cycad foliage of Pseudoctenis babinensis from the Bohemian Cenomanian. - Acta Musei Nationalis Pragae, Series B - Historia Naturalis, 64(2-4): 125-131.

Kvaček, J., Eklund, H. (2003): A report on newly recovered reproductive structures from the Cenomanian of Bohemia (Central Europe). - International Journal of Plant Sciences, 164(6): 1021-1039.

https://doi.org/10.1086/378824

Kvaček, J., Falcon-Lang, H., Dašková, J. (2005): A new Late Cretaceous ginkgoalean reproductive structure Nehvizdyella gen. nov. from the Czech Republic and its whole-plant reconstruction. - American Journal of Botany, 92(12): 1958-1969. https://doi.org/10.3732/ajb.92.12.1958

Kvaček, J., Knobloch, E. (1997): Representatives of the genus Nilsonia Brongniart from the Cenomanian of the Bohemian Massif (Czech Republic, Central Europe). Review of Palaeobotany and Palynology, 97: 41-52. https://doi.org/10.1016/S0034-6667(96)00064-4

Kvaček, J., Uličný, D., Svobodová, M., Špičáková, L. (2006): Cretaceous of Central Bohemia. - In: Fatka, O., Kvaček, J. (eds), $7^{\text {th }}$ European Palaeobotany-Palynology Conference: excursions guidebook: 7EPPC 2006, September 6-11, Czech Republic, Prague. National Museum, Prague, pp. 58-65.

Lindley, J., Hutton, W. (1834): The Fossil Flora of Great Britain; or figures and descriptions of the vegetable remains found in a fossil state in this country, Part II. John Ridgeway, London, 208 pp.

Nathorst, A. G. (1878): Om floran i Skånes kolförande bildningar. 1. Floran vid Bjuf, första häftet [About the flora from Skåne carbonaceous formations. 1. Flora at Bjuf, first report]. - Sveriges Geologiska Undersökning, C, 27: 1-52. (in Swedish)

Němejc, F. (1968): Paleobotanika III [Palaeobotany III]. Academia, Praha, 474 pp. (in Czech)

Pott, C., Kerp, H., Krings, M. (2007): Morphology and epidermal anatomy of Nilssonia (cycadalean foliage) from the Upper Triassi of Lunz (Lower Austria). - Review of Palaeobotany and Palynology, 143(3-4): 197-217. https://doi.org/10.1016/j.revpalbo.2006.07.007

Reuss, E. A. (1846): Die Versteinerungen der böhmischen Kreideformation [part 2]. - E. Schweitzerbart'sche Verlagsbuchhandlung, Stuttgart, 148 pp. 
Richards, J. T. (1884): On Scottish fossil cycadaceous leaves contained in the Hugh Miller Collection. - Proceedings of the Royal Physical Society of Edinburgh, 8: 116-123.

Scott, G. H. (1963): Uniformitarianism, the uniformity of nature, and paleoecology. - New Zealand Journal of Geology and Geophysics, 6(4): 510-527. https://doi.org/10.1080/00288306.1963.10420063

Schenk, A. (1867): Die Fossile Flora der Grenzschichten des Keuper und Lias Frankens. - C. W. Kreidel's Verlag, Wiesbaden, $231 \mathrm{pp}$.

Seward, A. C. (1911): The Jurassic flora of Sutherland. Transactions of the Royal Society of Edinburgh, 47: 643-709. https://doi.org/10.1017/S0080456800003872

Sternberg, K. M. (1838): Versuch einer geognostischbotanischen Darstellung der Flora der Vorwelt. Bd. II, H. 7/8. - Gotlieb Haase Söhne, Prag, pp. 81-220, pls 27-68A, B.

Thomas, H. H. (1913): The Fossil Flora of the Cleveland District of Yorkshire: I. The flora of the Marske Quarry.Quarterly Journal of the Geological Society of London, 69: 223-251. https://doi.org/10.1144/GSL.JGS.1913.069.01-04.17

Uličný, D., Kvaček, J., Svobodová, M., Špičáková, L. (1997): High-frequency sea-level fluctuations and plant habitats in Cenomanian fluvial to estuarine successions: Pecínov quarry, Bohemia. - Palaeogeography, Palaeoclimatology, Palaeoecology, 136: 165-197. https://doi.org/10.1016/S0031-0182(97)00033-3

Uličný, D., Špičáková, L., Grygar, R., Svobodová, M., Čech, S., Laurin, J. (2009): Palaeodrainage systems at the basal unconformity of the Bohemian Cretaceous Basin: roles of inherited fault systems and basement lithology during the onset of basin filling. - Bulletin of Geosciences, 84(4): 577-610.

https://doi.org/10.3140/bull.geosci.1128
Van Konijnenburg-van Cittert, J. H. A., van der Burgh, J. (1989): The flora from the Kimmeridgian (upper Jurassic) of Culgower, Sutherland, Scotland. - Review of Palaeobotany and Palynology, 61(1-2): 1-51. https://doi.org/10.1016/0034-6667(89)90060-2

Van Konijnenburg-van Cittert, J. H. A., Pott, C., Cleal, Ch. J., Zijlstra, G. (2017): Differentiation of the fossil leaves assigned to Taeniopteris, Nilssoniopteris and Nilssonia with a comparison to similar genera. - Review of Palaeobotany and Palynology, 237: 100-106. https://doi.org/10.1016/j.revpalbo.2016.11.009

Van Konijnenburg-van Cittert, J. H. A., Schmeissner, S., Hauptmann, S., Hauptmann, T. (1998): Neue Ergebnisse zu Ctenozamites wolfiana (Pteridospermae) und Pseudoctenis prossii nov. spec. (Cycadophyta) aus dem Unteren Lias (Jura, Bayern). - Documenta naturae, 117: 13-33.

Velenovský, J. (1885): Die Gymnospermen der Böhmischen Kreideformation. - E. Greger, Prag, 34 pp. https://doi.org/10.5962/bhl.title.109999

Veromann-Jürgenson, L.-L., Brodribb, T., Laanisto, L., Bruun-Lund, S., Niinemets, Ü., Nuño, S. L., Rinnan, R., Puglielli, G., Tosens, T. (2019): Predictability of leaf morphological traits for palaeoecological reconstruction: the case of leaf cuticle and leaf dry mass per area. International Journal of Plant Sciences, 181: 129-141. https://doi.org/10.1086/706342

Wang Qi (2011): (1995) Proposal to conserve the name Nilssonia with that spelling (fossil Cycadopsida, Nilssoniaceae). - Taxon, 60(1): 240.

Watson, J., Cusack, H. A. (2005): Cycadales of the English Wealden. - Monograph of the Palaeontological Society London, 158(622): 1-189. https://doi.org/10.1002/tax.601031 


\section{Explanations to the plates}

\section{PLATE 1}

Pseudoctenis babinensis J.KvaČEK, Pecínov quarry, unit 1, NM-F 4597c

1. Fragment of entire-margined pinna.

2. SEM of abaxial cuticle, outer surface showing cutinized rim.

3. SEM of abaxial cuticle, inner surface, haplocheilic stoma.

4. Light microscope preparation of abaxial cuticle showing six stomata with randomly oriented axes.

5. SEM of abaxial cuticle, inner surface showing haplocheilic stoma.

6. Light microscope preparation of abaxial cuticle showing two stomata in detail with subsidiary cells and ledges of guard cells.

7. Light microscope preparation of adaxial cuticle, ordinary cells.

8. SEM of adaxial cuticle, ordinary cells.

\section{PLATE 2}

Nilssonia mirovanae sp. nov., Pecínov quarry, unit 1, holotype NM-F 4698

1. Isolated entire-margined pinna fragment with parallel venation.

2. Light microscope preparation of abaxial cuticle showing costal and intercostal zones.

3. SEM of abaxial cuticle, outer surface, view of costal and intercostal zones.

4. Light microscope preparation of abaxial cuticle, view of costal and intercostal zone with stomatal rows and haplocheilic stomata.

5. SEM of abaxial cuticle, outer surface showing costal and intercostal zones with parallel wrinkles on costal zones.

6. Light microscope preparation of adaxial cuticle, elongate ordinary cells.

7. SEM of abaxial cuticle, outer surface, view of 3-6 (7) large papillae surrounding the stomatal chamber.

8. SEM of adaxial cuticle, inner surface, elongate ordinary cells.

9. SEM of abaxial cuticle, inner surface, detail of stomatal rows with haplocheilic stomata. 
PLATE 1
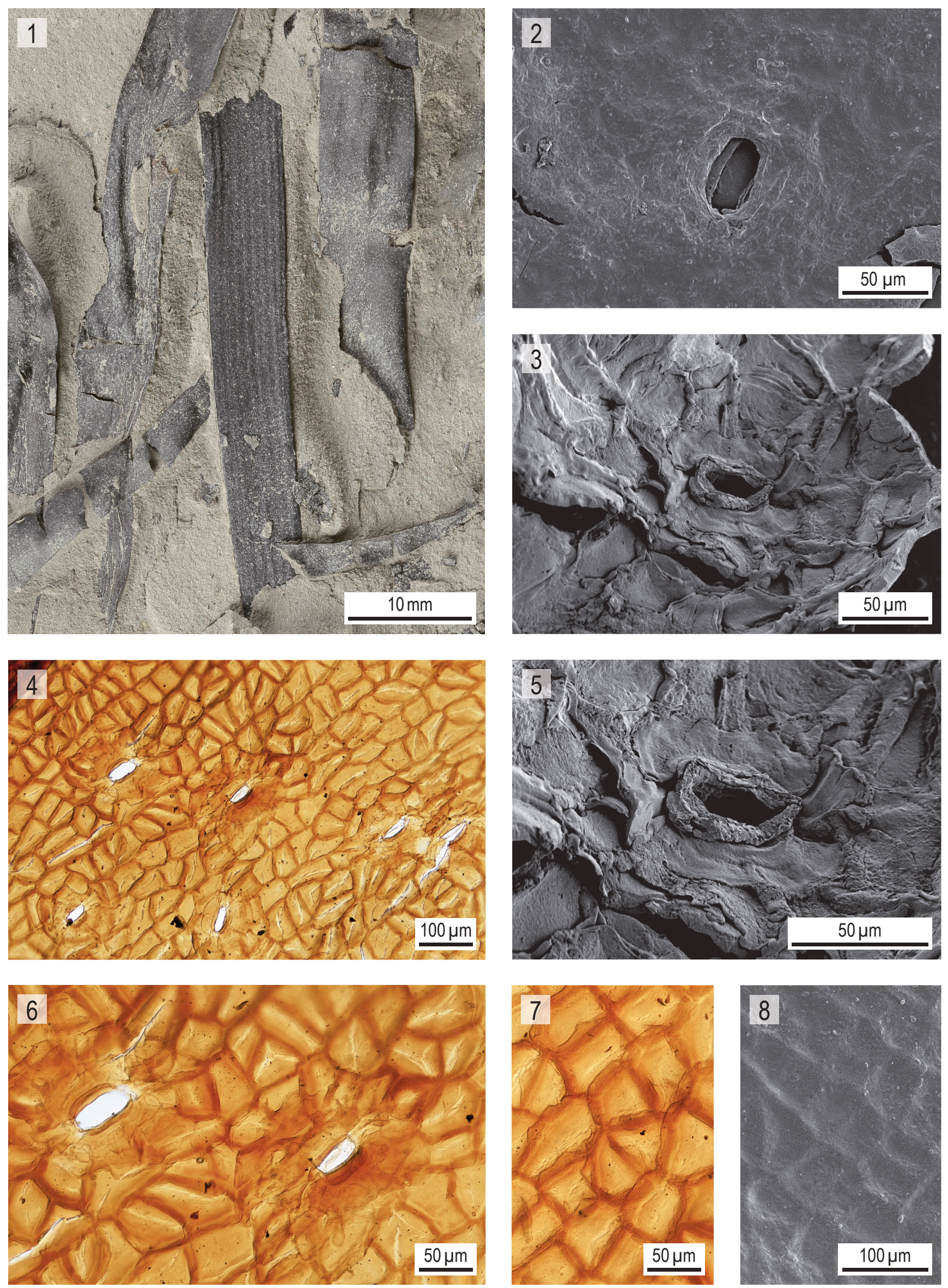
PLATE 2
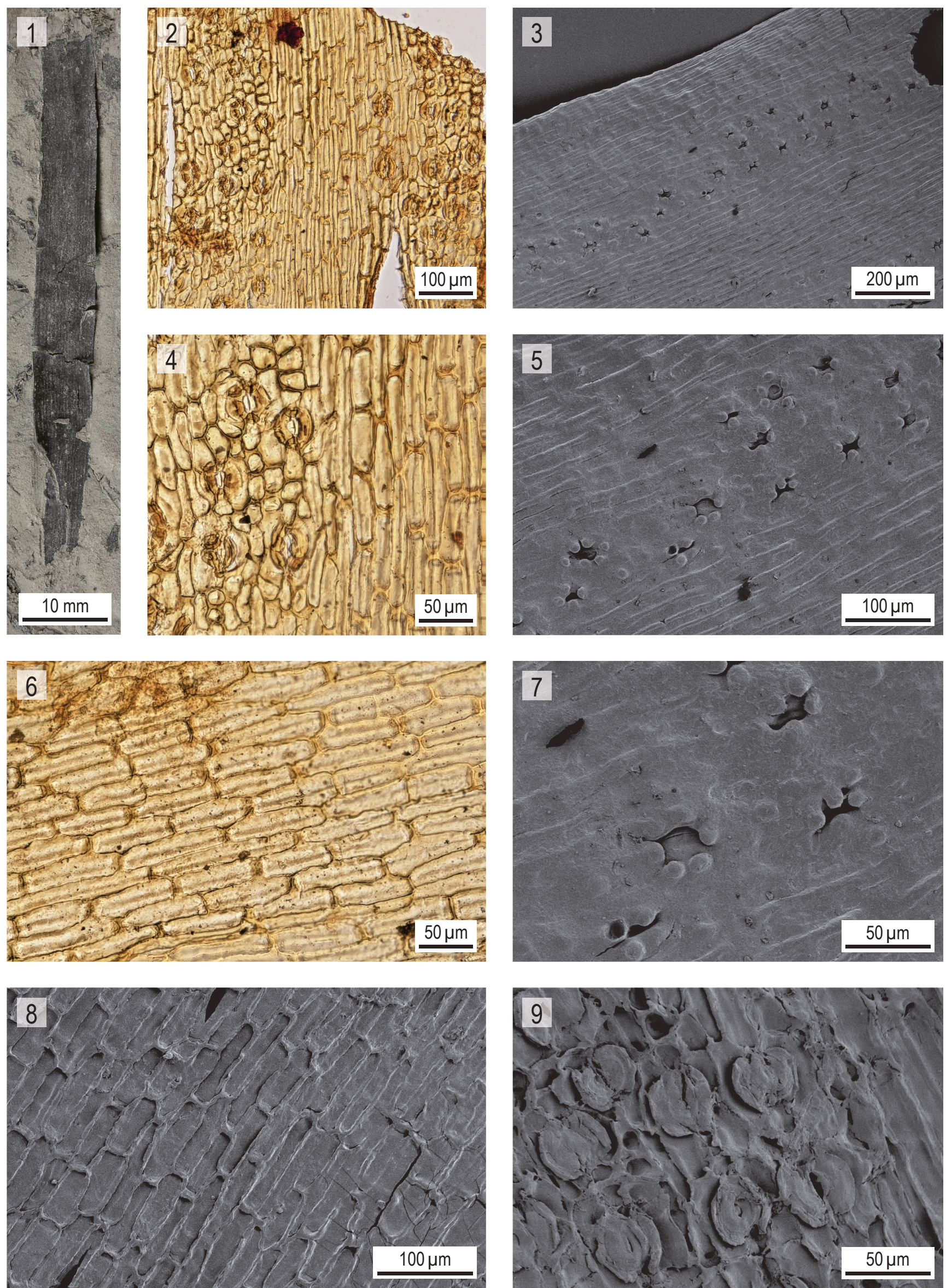